Article

\title{
High-Pressure Synthesis, Crystal Structure, and Photoluminescence Properties of $\beta-\mathrm{Y}_{2} \mathrm{~B}_{4} \mathrm{O}_{9}: \mathrm{Eu}^{3+}$
}

\author{
Birgit Fuchs ${ }^{1}$, Franziska Schröder ${ }^{2}$, Gunter Heymann ${ }^{1}$, Thomas Jüstel ${ }^{2}{ }^{\circledR}$ and \\ Hubert Huppertz ${ }^{1, *(D)}$ \\ 1 Institut für Allgemeine, Anorganische und Theoretische Chemie, Universität Innsbruck, Innrain 80-82, \\ 6020 Innsbruck, Austria; birgit.fuchs@uibk.ac.at (B.F.); gunter.heymann@uibk.ac.at (G.H.) \\ 2 Fachbereich Chemieingenieurwesen, FH Münster, Stegerwaldstraße 39, 48565 Steinfurt, Germany; \\ franziska.schroeder@fh-muenster.de (F.S.); tj@fh-muenster.de (T.J.) \\ * Correspondence: hubert.huppertz@uibk.ac.at; Fax: +43-(512)-507-57099
}

Received: 14 October 2019; Accepted: 9 November 2019; Published: 12 November 2019

check for updates

\begin{abstract}
A high-pressure/high-temperature experiment at 7.5 GPa and $1673 \mathrm{~K}$ led to the formation of the new compound $\beta-\mathrm{Y}_{2} \mathrm{~B}_{4} \mathrm{O}_{9}$. In contrast to the already known polymorph $\alpha-\mathrm{Y}_{2} \mathrm{~B}_{4} \mathrm{O}_{9}$, which crystallizes in the space group $C 2 / c$, the reported structure could be solved via single-crystal $\mathrm{X}$-ray diffraction in the triclinic space group $P \overline{1}$ (no. 2 ) and is isotypic to the already known lanthanide borates $\beta$ - $\mathrm{Dy}_{2} \mathrm{~B}_{4} \mathrm{O}_{9}$ and $\beta-\mathrm{Gd}_{2} \mathrm{~B}_{4} \mathrm{O}_{9}$. Furthermore, the photoluminescence of an europium doped sample of $\beta-\mathrm{Y}_{2} \mathrm{~B}_{4} \mathrm{O}_{9}: \mathrm{Eu}^{3+}(8 \%)$ was investigated.
\end{abstract}

Keywords: crystal structure; europium; high-pressure chemistry; photoluminescence; yttrium borate

\section{Introduction}

In the system $\mathrm{Y}-\mathrm{B}-\mathrm{O}$, only two modifications of $\mathrm{YBO}_{3}[1]$ (the low-temperature form $\pi-\mathrm{YBO}_{3}$ and the high-temperature form $\mu$ - $\mathrm{YBO}_{3}$ ) and the compound $\mathrm{Y}_{17.33}\left(\mathrm{BO}_{3}\right)_{4}\left(\mathrm{~B}_{2} \mathrm{O}_{5}\right)_{2} \mathrm{O}_{16}$ [2] (revised formula of $\mathrm{Y}_{3} \mathrm{BO}_{6}$ ) were known until 2016. Through the implementation of high-pressure conditions as an additional reaction parameter, three new compositions $\beta-\mathrm{Y}\left(\mathrm{BO}_{2}\right)_{3}[3], \alpha-\mathrm{Y}_{2} \mathrm{~B}_{4} \mathrm{O}_{9}$ [4], and $\mathrm{YB}_{7} \mathrm{O}_{12}$ [5] could be obtained by our group. As expected, all of the three latter compounds feature boron exclusively in a fourfold coordination by oxygen anions due to the applied high-pressure conditions. The anionic borate networks of these compounds are built up of corner-sharing and, in the case of $\alpha-\mathrm{Y}_{2} \mathrm{~B}_{4} \mathrm{O}_{9}$, also of edge-sharing $\mathrm{BO}_{4}$ tetrahedra. Not only the coordination number of boron is often increased under high-pressure conditions, but also the oxygen atoms can exhibit an increased coordination number, e.g., coordinated by three boron atoms $\left(\mathrm{O}^{[3]}\right)$, which is the case, for example, in the borates $\beta-\mathrm{Y}\left(\mathrm{BO}_{2}\right)_{3}$ and $\mathrm{YB}_{7} \mathrm{O}_{12}$.

In the following, we report on the high-pressure synthesis of $\beta-Y_{2} B_{4} O_{9}$, a hitherto missing polymorph of $\alpha-\mathrm{Y}_{2} \mathrm{~B}_{4} \mathrm{O}_{9}$. In contrast to the $\alpha$-modification, which was synthesized at $12.3 \mathrm{GPa}$, the $\beta$-phase was obtained at a lower pressure of $7.5 \mathrm{GPa}$ and does still contain planar $\mathrm{BO}_{3}$-groups and no edge-sharing $\mathrm{BO}_{4}$ tetrahedra. Furthermore, $\beta-\mathrm{Y}_{2} \mathrm{~B}_{4} \mathrm{O}_{9}$ is isotypic to the already known compounds $\beta$ - $\mathrm{Dy}_{2} \mathrm{~B}_{4} \mathrm{O}_{9}[6]$ and $\beta-\mathrm{Gd}_{2} \mathrm{~B}_{4} \mathrm{O}_{9}$ [7], which will be discussed in detail.

Rare earth borates have been known for their excellent properties as hosts for luminescent materials. They possess high quantum yields, an exceptional optical damage threshold, and a long lifetime, which makes them highly attractive for practical applications. The orthoborates $(\mathrm{Y}, \mathrm{Gd}) \mathrm{BO}_{3}: \mathrm{Eu}^{3+}$ and $\mathrm{YBO}_{3}: \mathrm{Tb}^{3+}$ are widely used, for example, in plasma display panels [8,9], but also co-doped inorganic phosphors like $\mathrm{YBO}_{3}: \mathrm{Eu}^{3+} / \mathrm{Tb}^{3+}[10]$ or $\mathrm{YAl}_{3}\left(\mathrm{BO}_{3}\right)_{4}: \mathrm{Eu}^{3+} / \mathrm{Tb}^{3+}$ or $\mathrm{Dy}^{3+} / \mathrm{Tm}^{3+}[11,12]$ are applied. Research in this field is ongoing, as a recently published work on the complete solid 
solution of $\alpha-\mathrm{Y}_{1-x} \mathrm{Eu}_{x} \mathrm{~B}_{5} \mathrm{O}_{9}$ shows [13]. In connection with these findings, we also investigated the photoluminescence properties of a $\beta-\mathrm{Y}_{2} \mathrm{~B}_{4} \mathrm{O}_{9}: \mathrm{Eu}^{3+}$ sample.

\section{Results and Discussion}

\subsection{Crystal Structure}

$\beta-\mathrm{Y}_{2} \mathrm{~B}_{4} \mathrm{O}_{9}$ crystallizes in the triclinic space group $P \overline{1}$ with the cell parameters $a=6.1463(2)$, $b=6.4053(2), c=7.4642(2) \AA, \alpha=102.59(2)^{\circ}, \beta=97.11(2)^{\circ}$, and $\gamma=102.46(2)^{\circ}$. The unit cell $\left(V=275.50(2) \AA^{3}\right)$ comprises $Z=2$ formula units. All the relevant data of the structure refinement are shown in Table 1.

Table 1. Crystal data and structure refinement of $\beta-\mathrm{Y}_{2} \mathrm{~B}_{4} \mathrm{O}_{9}$.

\begin{tabular}{|c|c|}
\hline Empirical Formula & $\beta-\mathrm{Y}_{2} \mathrm{~B}_{4} \mathrm{O}_{9}$ \\
\hline Molar mass, g.mol ${ }^{-1}$ & 365.06 \\
\hline Crystal system & triclinic \\
\hline Space group & $P \overline{1}$ (no. 2) \\
\hline \multicolumn{2}{|l|}{ Single-crystal data } \\
\hline$T, \mathrm{~K}$ & $277(2)$ \\
\hline Radiation & $\operatorname{Mo} \mathrm{K} \alpha(\lambda=71.07 \mathrm{pm})$ \\
\hline$a, \AA$ & $6.1463(2)$ \\
\hline$b, \AA$ & $6.4053(2)$ \\
\hline$c, \AA$ & $7.4642(2)$ \\
\hline$\alpha$, & $102.59(2)$ \\
\hline$\beta, \circ$ & $97.11(2)$ \\
\hline$\gamma, 0$ & $102.46(2)$ \\
\hline$V, \AA^{3}$ & $257.50(2)$ \\
\hline Z & 2 \\
\hline Calculated density, $\mathrm{g} \cdot \mathrm{cm}^{-3}$ & 4.401 \\
\hline Absorption coeff., $\mathrm{mm}^{-1}$ & 20.993 \\
\hline$F(000)$ & 340 \\
\hline Crystal size, $\mathrm{mm}^{3}$ & $0.050 \times 0.040 \times 0.020$ \\
\hline$\theta$ range, ${ }^{\circ}$ & $2.8-41.3$ \\
\hline Index ranges & $-11 \leq h \leq 11,-11 \leq k \leq 11,-13 \leq l \leq 13$ \\
\hline Reflections collected & 28267 \\
\hline Independent reflections & $3675\left[R_{\mathrm{int}}=0.0398\right]$ \\
\hline Refinement method & Full-matrix least-squares on $F^{2}$ \\
\hline Data/restraints/parameters & $3675 / 0 / 137$ \\
\hline Goodness-of-fit on $F^{2}$ & 1.058 \\
\hline Final $R 1 / w R 2$ indices $[I \geq 2 \sigma(I)]$ & $0.0210 / 0.0414$ \\
\hline Final $R 1 / w R 2$ indices (all data) & $0.0286 / 0.0431$ \\
\hline Largest diff. peak/hole, e $\AA^{-3}$ & $1.42 /-0.90$ \\
\hline
\end{tabular}

The crystal structure is built up of bands of $\mathrm{BO}_{4}$ tetrahedra, as well as planar $\mathrm{BO}_{3}$-groups. The bands run alongside the crystallographic $a$-axis (see Figure 1). Three $\mathrm{BO}_{4}$ tetrahedra form $\mathrm{B}_{3} \mathrm{O}_{9}$-rings, which are connected via two $\mathrm{BO}_{3}$-groups to form "sechser"-rings alongside the $a b$ plane. Additionally, the $\mathrm{B}_{3} \mathrm{O}_{9}$-rings are interconnected via two common corners to form four-membered rings (Figure 2). The $\mathrm{B}-\mathrm{O}$ distances range from 1.421 to $1.555 \AA$ within the $\mathrm{BO}_{4}$ tetrahedra. The mean value of $1.474 \AA$ corresponds very well with the average value of $1.476 \AA$ A reported by Zobetz [14]. The O-B-O angles lie in the rather wide range of 101.4-123.4 ${ }^{\circ}$, which was also reported for the isotypic compounds $\beta-\mathrm{Dy}_{2} \mathrm{~B}_{4} \mathrm{O}_{9}$ [6] and $\beta-\mathrm{Gd}_{2} \mathrm{~B}_{4} \mathrm{O}_{9}$ [7]. The average value of $109.4^{\circ}$ again is in good agreement with the reported value of $109.44^{\circ}$ [14]. In the nearly planar $\mathrm{BO}_{3}$-group $\left(\Sigma=359.6^{\circ}\right)$, the $\mathrm{B}-\mathrm{O}$ bond lengths vary between 1.360 and $1.391 \AA$, while the $\mathrm{O}-\mathrm{B}-\mathrm{O}$ angles range from 114.9 to $122.7^{\circ}$. Both average values of $1.373 \AA$ and $119.9^{\circ}$ are in good agreement with the expected values, as the mean $\mathrm{B}-\mathrm{O}$ distance for 
planar as well as non-planar $\mathrm{BO}_{3}$-groups is $1.37 \AA$ [15] and the perfect angle in a planar $\mathrm{BO}_{3}$-group would be $120^{\circ}$. Similar results were found for $\beta-\mathrm{Dy}_{2} \mathrm{~B}_{4} \mathrm{O}_{9}[6]$ and $\beta-\mathrm{Gd}_{2} \mathrm{~B}_{4} \mathrm{O}_{9}$ [7] $\left(1.376 \AA / 119.9^{\circ}\right)$. The positional parameters, as well as the $\mathrm{B}-\mathrm{O}$ distances and the $\mathrm{O}-\mathrm{B}-\mathrm{O}$ angles can be found in Tables $2-4$.

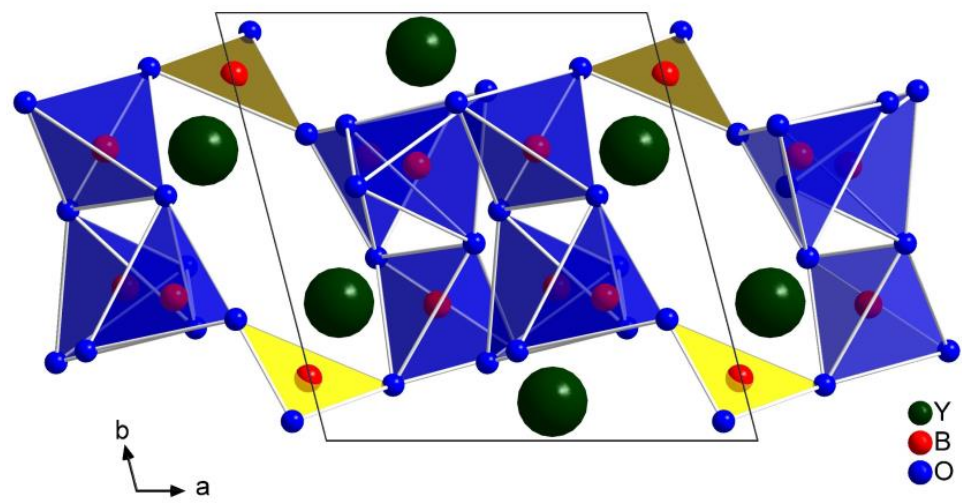

Figure 1. The interconnected $\mathrm{BO}_{4}$ tetrahedra and $\mathrm{BO}_{3}$ groups in $\beta-\mathrm{Y}_{2} \mathrm{~B}_{4} \mathrm{O}_{9}$ form bands along the $a$-axis.

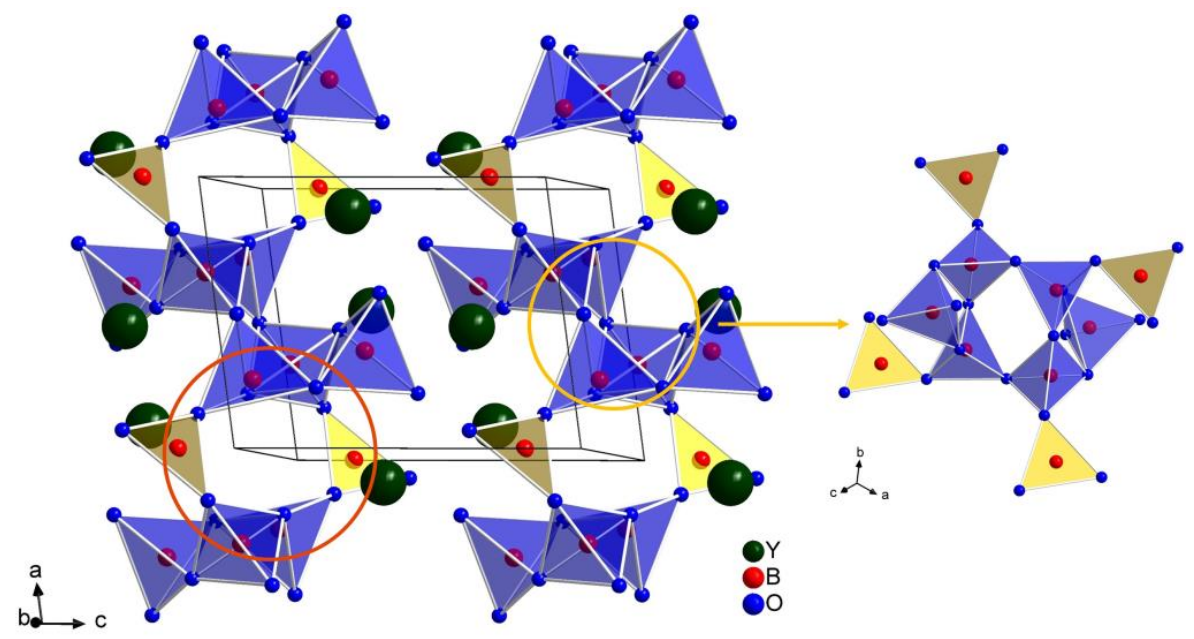

Figure 2. Crystal structure of $\beta-\mathrm{Y}_{2} \mathrm{~B}_{4} \mathrm{O}_{9}$ forming six-membered rings (one encircled in orange) and four-membered rings (one encircled in yellow and shown individually on the right).

Table 2. Atomic coordinates and equivalent isotropic displacement parameters $U_{\text {eq }} / \AA^{2}$. $U_{\text {eq }}$ is defined as one third of the trace of the orthogonalized $U_{\mathrm{ij}}$ tensor (standard deviations in parentheses). All atoms are located on Wyckoff-site $2 i$.

\begin{tabular}{ccccc}
\hline Atom & $\boldsymbol{x}$ & $\boldsymbol{y}$ & $\boldsymbol{z}$ & $\boldsymbol{U}_{\text {eq }}$ \\
\hline Y1 & $0.8881(1)$ & $0.6775(1)$ & $0.3598(1)$ & $0.0022(1)$ \\
Y2 & $0.5473(1)$ & $0.0910(1)$ & $0.2854(1)$ & $0.0030(1)$ \\
B1 & $0.7321(3)$ & $0.3347(3)$ & $0.9806(2)$ & $0.0052(2)$ \\
B2 & $0.6618(3)$ & $0.6822(3)$ & $0.9275(2)$ & $0.0053(2)$ \\
B3 & $0.6255(3)$ & $0.3572(3)$ & $0.6505(2)$ & $0.0056(2)$ \\
B4 & $0.0050(3)$ & $0.8543(3)$ & $0.8111(2)$ & $0.0064(2)$ \\
O1 & $0.5040(2)$ & $0.7902(2)$ & $0.0204(2)$ & $0.0057(2)$ \\
O2 & $0.4200(2)$ & $0.1827(2)$ & $0.5554(2)$ & $0.0064(2)$ \\
O3 & $0.2360(2)$ & $0.7364(2)$ & $0.2113(2)$ & $0.0060(2)$ \\
O4 & $0.7795(2)$ & $0.4063(2)$ & $0.5228(2)$ & $0.0064(2)$ \\
O5 & $0.1375(2)$ & $0.7163(2)$ & $0.8570(2)$ & $0.0069(2)$ \\
O6 & $0.5394(2)$ & $0.5388(2)$ & $0.7479(2)$ & $0.0065(2)$ \\
O7 & $0.7741(2)$ & $0.5720(2)$ & $0.0412(2)$ & $0.0058(2)$ \\
O8 & $0.8122(2)$ & $0.8700(2)$ & $0.8812(2)$ & $0.0072(2)$ \\
O9 & $0.0677(2)$ & $0.9547(2)$ & $0.6761(2)$ & $0.0077(2)$ \\
\hline
\end{tabular}


Table 3. Interatomic B-O distances/ $\AA$ for $\beta-\mathrm{Y}_{2} \mathrm{~B}_{4} \mathrm{O}_{9}$ (standard deviations in parentheses).

\begin{tabular}{|c|c|c|c|c|c|}
\hline \multicolumn{2}{|c|}{ Bond } & \multirow{2}{*}{$\begin{array}{l}\text { Distance } \\
1.444(2)\end{array}$} & \multicolumn{2}{|c|}{ Bond } & \multirow{2}{*}{$\begin{array}{c}\text { Distance } \\
1.421(2)\end{array}$} \\
\hline B1 & $-\mathrm{O} 7$ & & B2 & $-\mathrm{O} 7$ & \\
\hline & $-\mathrm{O} 3$ & $1.457(2)$ & & $-\mathrm{O} 6$ & $1.457(2)$ \\
\hline & $-\mathrm{O} 1$ & $1.497(2)$ & & $-\mathrm{O} 1$ & $1.466(2)$ \\
\hline & $-\mathrm{O} 5$ & $1.505(2)$ & & $-\mathrm{O} 8$ & $1.483(2)$ \\
\hline & $\varnothing$ & 1.476 & & $\varnothing$ & 1.457 \\
\hline \multirow[t]{5}{*}{ B3 } & $-\mathrm{O} 4$ & $1.459(2)$ & B4 & $-\mathrm{O} 9$ & $1.360(2)$ \\
\hline & $-\mathrm{O} 6$ & $1.468(2)$ & & $-\mathrm{O} 8$ & $1.367(2)$ \\
\hline & $-\mathrm{O} 2$ & $1.474(2)$ & & $-\mathrm{O} 5$ & $1.391(2)$ \\
\hline & $-\mathrm{O} 3$ & $1.555(2)$ & & & \\
\hline & $\varnothing$ & 1.489 & & $\varnothing$ & 1.373 \\
\hline
\end{tabular}

Table 4. Bond angles $/{ }^{\circ}$ for $\beta-\mathrm{Y}_{2} \mathrm{~B}_{4} \mathrm{O}_{9}$ (standard deviations in parentheses).

\begin{tabular}{cccc}
\hline Bond & Angle & Bond & Angle \\
\hline O1-B1-O5 & $101.4(2)$ & O1-B2-O8 & $101.7(2)$ \\
O7-B1-O5 & $101.7(2)$ & O6-B2-O8 & $104.9(2)$ \\
O3-B1-O1 & $104.0(2)$ & O6-B2-O1 & $108.3(2)$ \\
O7-B1-O3 & $111.6(2)$ & O7-B2-O1 & $112.6(2)$ \\
O7-B1-O1 & $114.9(2)$ & O7-B2-O6 & $113.6(2) 119.1(5)$ \\
O3-B1-O5 & $123.4(2)$ & O7-B2-O8 & $114.8(2)$ \\
$\varnothing$ & 109.5 & $\varnothing$ & 109.3 \\
\hline O4-B3-O3 & $103.2(2)$ & O9-B4-O5 & $114.9(2)$ \\
O6-B3-O2 & $104.3(2)$ & O9-B4-O8 & $122.1(2)$ \\
O2-B3-O3 & $107.8(2)$ & O8-B4-O5 & $122.7(2)$ \\
O4-B3-O2 & $112.0(2)$ & & \\
O6-B3-O3 & $112.0(2)$ & & \\
O4-B3-O6 & $117.4(2)$ & & 119.9 \\
$\varnothing$ & 109.5 & $\varnothing$ & \\
\hline
\end{tabular}

The $\mathrm{Y}^{3+}$ cations are located in the voids between the anionic borate bands. There are two crystallographically independent yttrium atoms in the structure: The first one is coordinated by nine oxygen atoms, the second one by ten oxygen atoms (see Figure 3). The $\mathrm{Y}-\mathrm{O}$ distances lie in the range from 2.256 to $2.645 \AA$ and are displayed in Table 5. This conforms to the reported values of $\beta-\mathrm{Dy}_{2} \mathrm{~B}_{4} \mathrm{O}_{9}$ (2.263-2.652 $\AA$ ) and also to other high-pressure yttrium borates like $\beta-\mathrm{Y}\left(\mathrm{BO}_{2}\right)_{3}(2.383-2.419 \AA)$ [3], $\alpha-\mathrm{Y}_{2} \mathrm{~B}_{4} \mathrm{O}_{9}(2.401-2.602 \AA)$ [4], and $\mathrm{YB}_{7} \mathrm{O}_{12}(2.308-2.659 \AA)$ [5].

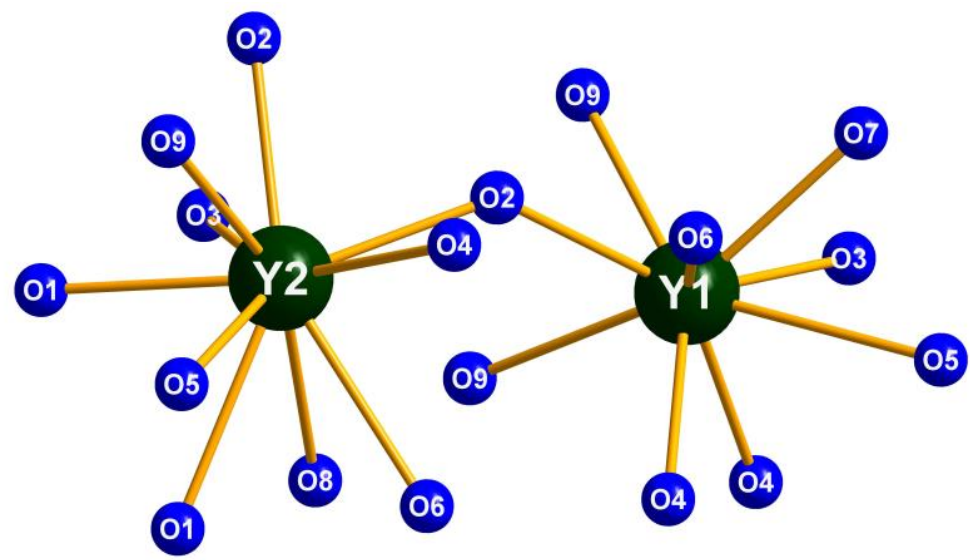

Figure 3. Coordination spheres of the two crystallographically independent yttrium sites in the crystal structure of $\beta-\mathrm{Y}_{2} \mathrm{~B}_{4} \mathrm{O}_{9}$. 
Table 5. Interatomic $\mathrm{Y}-\mathrm{O}$ distances/Å for $\beta-\mathrm{Y}_{2} \mathrm{~B}_{4} \mathrm{O}_{9}$ (standard deviations in parentheses).

\begin{tabular}{|c|c|c|c|c|c|}
\hline \multicolumn{2}{|c|}{ Bond } & \multirow{2}{*}{$\begin{array}{l}\text { Distance } \\
2.299(2)\end{array}$} & \multicolumn{2}{|c|}{ Bond } & \multirow{2}{*}{$\begin{array}{c}\text { Distance } \\
2.256(2)\end{array}$} \\
\hline Y1 & $-\mathrm{O} 7$ & & $\mathrm{Y} 2$ & $-\mathrm{O} 2$ & \\
\hline & $-\mathrm{O} 4$ & $2.338(2)$ & & $-\mathrm{O} 2$ & $2.351(2)$ \\
\hline & $-\mathrm{O} 4$ & $2.359(2)$ & & $-\mathrm{O} 1$ & $2.384(2)$ \\
\hline & $-\mathrm{O} 2$ & $2.359(2)$ & & $-\mathrm{O} 4$ & $2.414(2)$ \\
\hline & -09 & $2.390(2)$ & & -09 & $2.436(2)$ \\
\hline & $-\mathrm{O} 3$ & $2.523(2)$ & & $-\mathrm{O} 8$ & $2.487(2)$ \\
\hline & -09 & $2.573(2)$ & & $-\mathrm{O} 3$ & $2.538(2)$ \\
\hline & $-\mathrm{O} 6$ & $2.625(2)$ & & $-\mathrm{O} 5$ & $2.541(2)$ \\
\hline & $-\mathrm{O} 5$ & $2.645(2)$ & & $-\mathrm{O} 1$ & $2.563(2)$ \\
\hline & & & & $-\mathrm{O} 6$ & $2.596(2)$ \\
\hline & $\varnothing$ & 2.457 & & $\varnothing$ & 2.457 \\
\hline
\end{tabular}

The charge distributions and bond valences were calculated using both the bond-length/bond-strength (BLBS; $\Sigma V)$ [16,17], and the CHARDI concept $(\Sigma Q)$ [18]. The results are shown in Table 6 and they are in good agreement with the expected values of +3 for yttrium and boron and -2 for oxygen.

Table 6. Charge distributions according to both, the bond-length/bond-strength $\left(\sum V\right)$ and the CHARDI $\left(\sum Q\right)$ concept.

\begin{tabular}{cccccccccc}
\hline Method & Y1 & Y2 & B1 & B2 & B3 & B4 & & & \\
\hline$\sum V$ & +2.92 & +3.19 & +3.02 & +3.18 & +2.92 & +2.99 & & & \\
$\sum Q$ & +2.97 & +3.01 & +3.00 & +2.97 & +3.03 & +3.03 & & & \\
\hline & O1 & O2 & O3 & O4 & O5 & O6 & O7 & O8 & O9 \\
\hline$\sum V$ & -2.09 & -2.09 & -1.90 & -1.95 & -2.07 & -1.97 & -2.16 & -2.03 & -1.94 \\
$\sum Q$ & -1.98 & -2.05 & -1.86 & -2.03 & -1.99 & -1.95 & -2.18 & -1.97 & -1.99 \\
\hline
\end{tabular}

Further details of the crystal structure investigation may be obtained from The Cambridge Crystallographic Data Centre CCDC/FIZ Karlsruhe deposition service via www.ccdc.cam.ac.uk/ structures on quoting the deposition number CCDC-1955299 for $\beta-\mathrm{Y}_{2} \mathrm{~B}_{4} \mathrm{O}_{9}$. The cif- and checkcif-files are also available in the Supplementary Materials.

\subsection{Elemental Analysis}

The semiquantitative EDX measurements were performed to prove the presence of europium in the $\beta-\mathrm{Y}_{2} \mathrm{~B}_{4} \mathrm{O}_{9}$ host. Figure 4 shows the resulting EDX spectrum, which clearly confirms that europium is present in the structure. The measured and averaged values from the measurements can be seen in Table 7. Additionally, small amounts of silicon were detected in three of the measurements, which most likely originates from the agate mortar that was used to homogenize the sample, which is well known for hard borates.

\subsection{Photoluminescence Properties}

The emission spectrum of a $\beta-\mathrm{Y}_{2} \mathrm{~B}_{4} \mathrm{O}_{9}: \mathrm{Eu}^{3+}(8 \%)$ single-crystal, obtained upon excitation by a blue laser diode $\left(\lambda_{\text {exc }}=420 \mathrm{~nm}\right)$ is shown in Figure 5. The Eu ${ }^{3+}$ transitions can be assigned to the ${ }^{5} \mathrm{D}_{0} \rightarrow{ }^{7} \mathrm{~F}_{\mathrm{J}}$ $(\mathrm{J}=0-4)$ transitions in the following way: the ${ }^{5} \mathrm{D}_{0} \rightarrow{ }^{7} \mathrm{~F}_{0}$ transition corresponds to the single peak at $587 \mathrm{~nm}$. The signals between 594 and $596 \mathrm{~nm}$ belong to the magnetic dipole transition $\left({ }^{5} \mathrm{D}_{0} \rightarrow{ }^{7} \mathrm{~F}_{1}\right)$, while the strongest bands in the spectrum from 610 to $623 \mathrm{~nm}$ can be assigned to the electric dipole transition $\left({ }^{5} \mathrm{D}_{0} \rightarrow{ }^{7} \mathrm{~F}_{2}\right)$. The ${ }^{5} \mathrm{D}_{0} \rightarrow{ }^{7} \mathrm{~F}_{3}$ transitions occur as very weak signals in the range from 650 to 657 $\mathrm{nm}$, and the signals between 684 and $705 \mathrm{~nm}$ belong to the ${ }^{5} \mathrm{D}_{0} \rightarrow{ }^{7} \mathrm{~F}_{4}$ transitions [19]. The origin of the weak emission at $578-580 \mathrm{~nm}$ is the ${ }^{5} \mathrm{D}_{0} \rightarrow{ }^{7} \mathrm{~F}_{1}$ transition, since $580 \mathrm{~nm}$ corresponds to an energy of 
$17.241 \mathrm{~cm}^{-1}$. For the assignment of the transition, which matches the energy, the Dieke diagram was used [20].

a)
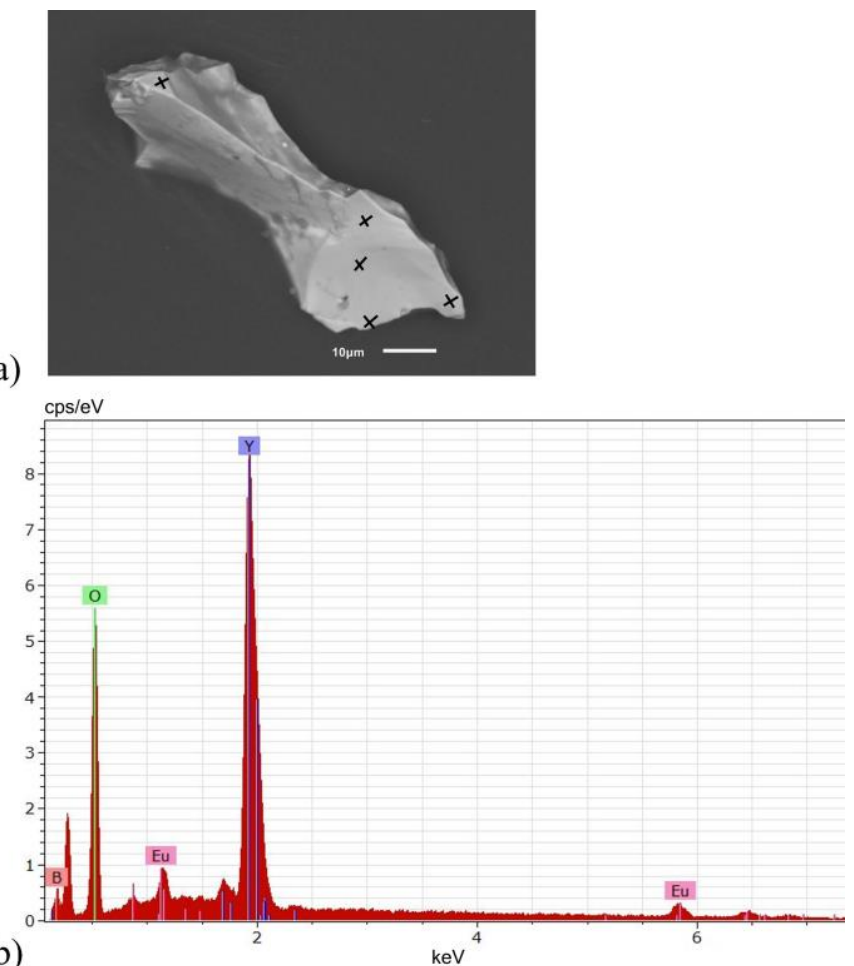

Figure 4. (a) Crystal used for the EDX measurement (crosses indicate the measured positions); (b) EDX spectrum of $\beta-\mathrm{Y}_{2} \mathrm{~B}_{4} \mathrm{O}_{9}: \mathrm{Eu}^{3+}(8 \%)$. The unindexed peak at $\sim 0.3 \mathrm{keV}$ originates from carbon used for the sputtering process.

Table 7. Measured composition (normalized to $100 \%$ ) of $\beta-\mathrm{Y}_{2} \mathrm{~B}_{4} \mathrm{O}_{9}: \mathrm{Eu}^{3+}$ (8\%) (wt \%). Accuracy for all measured values $\pm 3 \%$.

\begin{tabular}{cccccc}
\hline Element & Y & B & O & Eu & Si \\
\hline M1 & 45.0 & 15.5 & 36.1 & 3.0 & 0.4 \\
M2 & 41.2 & 13.0 & 33.2 & 12.5 & 0.1 \\
M3 & 43.4 & 14.0 & 34.1 & 8.6 & 0.0 \\
M4 & 42.1 & 15.3 & 34.9 & 7.7 & 0.1 \\
M5 & 42.5 & 13.6 & 34.1 & 9.8 & 0.0 \\
\hline average & $42.8(3)$ & $14.3(2)$ & $34.5(2)$ & $8.3(7)$ & 0.1 \\
\hline expected & 46.1 & 11.7 & 38.9 & 3.3 & \\
\hline
\end{tabular}

As can be seen in Figure 5, the so-called hypersensitive ${ }^{5} \mathrm{D}_{0} \rightarrow{ }^{7} \mathrm{~F}_{2}$ transition exhibits the strongest bands in the spectrum. For perfect inversion symmetry, e.g., for $\mathrm{Eu}^{3+}$ located onto a regular octahedral site, the intensity of the ${ }^{5} \mathrm{D}_{0} \rightarrow{ }^{7} \mathrm{~F}_{2}$ transition should be zero and thus the asymmetry ratio $\mathrm{R}$ should be zero too. However, since the ${ }^{5} \mathrm{D}_{0} \rightarrow{ }^{7} \mathrm{~F}_{2}$ transition is hypersensitive, any tiny distortion of the inversion symmetry will result in an increase of its intensity and thus in the $\mathrm{R}$ value. It is not uncommon that the ${ }^{5} \mathrm{D}_{0} \rightarrow{ }^{7} \mathrm{~F}_{2}$ transition is 10 times more intense than the ${ }^{5} \mathrm{D}_{0} \rightarrow{ }^{7} \mathrm{~F}_{1}$ transition. However, the correlation is not simple and correlating the luminescence color or symmetry ratio with a particular site symmetry or deviation from inversion symmetry is rather difficult. 


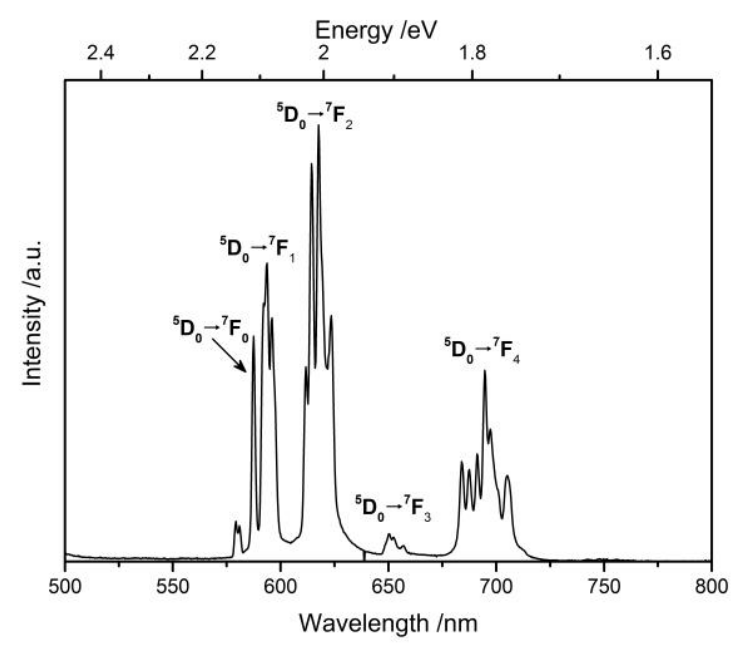

Figure 5. Emission spectrum of a $\beta-\mathrm{Y}_{2} \mathrm{~B}_{4} \mathrm{O}_{9}: \mathrm{Eu}^{3+}(8 \%)$ single-crystal obtained upon excitation at $448 \mathrm{~nm}$.

The factor $\mathrm{R}$ for the compound introduced in this paper has been calculated on the basis of the publication of K. Binnemans [19]. That leads to an integral of 9.4286 for the ${ }^{5} \mathrm{D}_{0} \rightarrow{ }^{7} \mathrm{~F}_{2}$ transition $(604-635 \mathrm{~nm})$ and to an integral of 1.8115 for the ${ }^{5} \mathrm{D}_{0} \rightarrow{ }^{7} \mathrm{~F}_{1}$ transition $(589-604 \mathrm{~nm})$. The $\mathrm{R}$ factor is calculated by $\mathrm{I}\left({ }^{5} \mathrm{D}_{0} \rightarrow{ }^{7} \mathrm{~F}_{2}\right) / \mathrm{I}\left({ }^{5} \mathrm{D}_{0} \rightarrow{ }^{7} \mathrm{~F}_{1}\right)$ and leads to $\mathrm{R}=5.2$.

\section{Experimental Section}

\subsection{Synthesis}

$\beta-\mathrm{Y}_{2} \mathrm{~B}_{4} \mathrm{O}_{9}$ was synthesized via a high-pressure/high-temperature experiment. For this synthesis, the starting materials $\mathrm{Y}_{2} \mathrm{O}_{3}$ (ChemPUR, Karlsruhe, Germany, 99.9\%) and $\mathrm{H}_{3} \mathrm{BO}_{3}$ (Carl Roth, Karlsruhe, Germany, $>99.8 \%$ ) were ground together under ambient conditions in the stoichiometric ratio of 1:4.05, i.e., with a $5 \%$ excess of boric acid. The homogenized mixture was encapsulated in platinum foil, placed into a crucible made of $\alpha$-BN and closed with a lid out of the same material (Henze Boron Nitride Products AG, Lauben, Germany). The crucible was placed into an 18/11 assembly, which was compressed and heated in a multianvil device based on a Walker-type module and a $1000 \mathrm{t}$ downstroke press (both devices from Max Voggenreiter $\mathrm{GmbH}$, Mainleus, Germany). A detailed description of the experimental setup can be found in the literature [21-23].

The sample was compressed to $7.5 \mathrm{GPa}$ in $200 \mathrm{~min}$, followed by a heating period of $10 \mathrm{~min}$ to $1673 \mathrm{~K}$. This temperature was kept for $60 \mathrm{~min}$, before the sample was slowly cooled down to room temperature in the following $240 \mathrm{~min}$. Afterwards, the heating was switched off and the 600 min decompression process started. The recovered octahedral pressure medium was broken apart and the product carefully separated from the surrounding BN crucible and the platinum capsule. $\beta-\mathrm{Y}_{2} \mathrm{~B}_{4} \mathrm{O}_{9}$ could be obtained as colorless, irregular shaped crystals beside a significant amount of white microcrystalline powder.

The synthesis of the europium doped sample was carried out under the same conditions with $\mathrm{Y}_{2} \mathrm{O}_{3}$, $\mathrm{Eu}_{2} \mathrm{O}_{3}$ (Smart Elements, Wien, Austria, $99.99 \%$ ) and $\mathrm{H}_{3} \mathrm{BO}_{3}$ in the stoichiometric ratio of 0.46:0.04:2 as starting materials.

The $X$-ray powder diffraction data revealed that the reaction product is composed of $\beta-Y_{2} B_{4} \mathrm{O}_{9}$ (about $59 \%$ ) and $\pi-\mathrm{YBO}_{3}$ as the main side phase. Attempts to synthesize a pure sample of $\beta-\mathrm{Y}_{2} \mathrm{~B}_{4} \mathrm{O}_{9}$ were not successful, $\pi-\mathrm{YBO}_{3}$ always occurs as the main side product in the $\mathrm{X}$-ray powder pattern.

\subsection{Single-Crystal Structure Analysis}

The intensity data of a $\beta-Y_{2} B_{4} \mathrm{O}_{9}$ single-crystal was collected using a Bruker D8 Quest Kappa diffractometer equipped with a Photon 100 CMOS detector. An Incoatec microfocus X-ray tube in multilayer optics generated the monochromatized Mo K $\alpha$ radiation $(\lambda=0.7107 \AA)$. A multiscan 
absorption correction of the intensity data with SADABS 2014/5 [24] was applied on the data. For the structure solution and parameter refinement, the software SHELXS/L-2013 [25,26], as implemented in the program WINGX-2013.3 [27], was employed. No systematic extinctions were observed, which led to the only possible space groups $P 1$ and $P \overline{1}$. During the refinement, the centrosymmetric space group was found to be correct, which is in agreement with the results from the isotypic compounds $\beta$ - $\mathrm{Dy}_{2} \mathrm{~B}_{4} \mathrm{O}_{9}$ and $\beta-\mathrm{Gd}_{2} \mathrm{~B}_{4} \mathrm{O}_{9}$. All atoms could be refined with anisotropic displacement parameters.

\subsection{Energy-Dispersive X-ray Spectroscopy (EDX)}

A semiquantitative EDX measurement was performed in high vacuum on a Jeol JSM-6010LA scanning electron microscope (SEM) (Bruker, Billerica, MA, USA). The crystal was attached to a carbon tape and coated with carbon. The measurement was carried out under an acceleration voltage of $15 \mathrm{kV}$, a working distance of $14 \mathrm{~mm}$, and a measurement time of $60 \mathrm{~s}$. Five different spots on the crystal were selected, the measured chemical composition was averaged and normalized to $100 \%$.

\subsection{Luminescence Spectroscopy}

The emission spectrum of a $\beta-\mathrm{Y}_{2} \mathrm{~B}_{4} \mathrm{O}_{9}$ single-crystal was collected using a setup equipped with an AvaSpec2048 spectrometer (AVANTES, Apeldoorn, Netherlands). A blue laser diode (THORLABS, Newton, MA, USA) with $448 \mathrm{~nm}$ wavelength was used as excitation source. Prior to the experiments, a spectral radiance calibration of the setup was carried out using a tungsten-halogen calibration lamp. The software AVA AvaSoft full version 7 was employed for data handling. The emission spectrum was measured in the range of $200-1100 \mathrm{~nm}$ and was background-corrected.

\section{Conclusions}

The new compound $\beta-\mathrm{Y}_{2} \mathrm{~B}_{4} \mathrm{O}_{9}$, which is isotypic to $\beta$ - $\mathrm{Dy}_{2} \mathrm{~B}_{4} \mathrm{O}_{9}$ and $\beta-\mathrm{Gd}_{2} \mathrm{~B}_{4} \mathrm{O}_{9}$, was synthesized under the high-pressure/high-temperature conditions of $7.5 \mathrm{GPa}$ and $1673 \mathrm{~K}$ using a Walker-type multianvil press. The structure was characterized via single-crystal X-ray analysis and it is built up of $\mathrm{BO}_{3}$ groups as well as $\mathrm{BO}_{4}$ tetrahedra, forming three-, four-, and six-membered rings.

The experiments to substitute yttrium with europium were successful, as proven by the EDX measurements of a $\beta-\mathrm{Y}_{2} \mathrm{~B}_{4} \mathrm{O}_{9}: \mathrm{Eu}^{3+}(8 \%)$ crystal. Thus, the luminescence properties of the europium-substituted sample were investigated. The emission spectrum shows typical $\mathrm{Eu}^{3+}$ photoluminescence with the strongest peak originating from the ${ }^{5} \mathrm{D}_{0} \rightarrow{ }^{7} \mathrm{~F}_{2}$ electric dipole transition.

Supplementary Materials: The following are available online at http://www.mdpi.com/2304-6740/7/11/136/s1, the CIF and the checkCIF output files.

Author Contributions: Conceptualization, B.F. and H.H.; Validation, B.F., F.S. and G.H.; Formal Analysis, B.F., F.S. and G.H.; Investigation, F.S.; Writing-Original Draft Preparation, B.F.; Writing-Review \& Editing, all authors; Supervision, T.J. and H.H.

Funding: This research received no external funding.

Acknowledgments: We thank M. Tribus for the EDX measurements and OSRAM Opto Semiconductors GmbH for the support in the investigation of the luminescence properties.

Conflicts of Interest: The authors declare no conflict of interest.

\section{References}

1. Levin, E.M.; Roth, R.S.; Martin, J.B. Polymorphism of $\mathrm{ABO}_{3}$ type Rare Earth Borates. Am. Mineral. J. Earth Planet. Mater. 1961, 46, 1030-1055.

2. Lin, J.H.; Zhou, S.; Yang, L.Q.; Yao, G.Q.; Su, M.Z.; You, L.P. Structure and Luminescent Properties of $\mathrm{Y}_{17.33}\left(\mathrm{BO}_{3}\right)_{4}\left(\mathrm{~B}_{2} \mathrm{O}_{5}\right)_{2} \mathrm{O}_{16}$. J. Solid State Chem. 1997, 134, 158-163. [CrossRef]

3. Schmitt, M.K.; Huppertz, H. $\beta-\mathrm{Y}\left(\mathrm{BO}_{2}\right)_{3}-\mathrm{A}$ new member of the $\beta-\mathrm{Ln}\left(\mathrm{BO}_{2}\right)_{3}(\mathrm{Ln}=\mathrm{Nd}, \mathrm{Sm}, \mathrm{Gd}-\mathrm{Lu})$ structure family. Z. Naturforsch. B 2017, 72, 983-988. [CrossRef] 
4. Schmitt, M.K.; Huppertz, H. High-pressure synthesis and crystal structure of $\alpha-\mathrm{Y}_{2} \mathrm{~B}_{4} \mathrm{O}_{9}$. Z. Naturforsch. $B$ 2017, 72, 977-982. [CrossRef]

5. Fuchs, B.; Schmitt, M.K.; Wurst, K.; Huppertz, H. High-Pressure Synthesis and Crystal Structure of the Highly Condensed Yttrium Borate $\mathrm{YB}_{7} \mathrm{O}_{12}$. Eur. J. Inorg. Chem. 2019, 2019, 271-276. [CrossRef]

6. Huppertz, H.; Altmannshofer, S.; Heymann, G. High-pressure preparation, crystal structure, and properties of the new rare-earth oxoborate $\beta-\mathrm{Dy}_{2} \mathrm{~B}_{4} \mathrm{O}_{9}$. J. Solid State Chem. 2003, 170, 320-329. [CrossRef]

7. Emme, H.; Huppertz, H. High-pressure synthesis of the new rare-earth oxoborate $\beta-\mathrm{Gd}_{2} \mathrm{~B}_{4} \mathrm{O}_{9}$. Acta Crystallogr. 2005, 61, i23-i24.

8. Lin, J.; Sheptyakov, D.; Wang, Y.; Allenspach, P. Structures and Phase Transition of Vaterite-Type Rare Earth Orthoborates: A Neutron Diffraction Study. Chem. Mater. 2004, 16, 2418-2424. [CrossRef]

9. Pitscheider, A.; Kaindl, R.; Oeckler, O.; Huppertz, H. The crystal structure of pi-ErBO ${ }_{3}$ : New single-crystal data for an old problem. J. Solid State Chem. 2011, 184, 149-153. [CrossRef]

10. Zhang, X.; Zhao, Z.; Zhang, X.; Marathe, A.; Cordes, D.B.; Weeks, B.; Chaudhuri,J. Tunable photoluminescence and energy transfer of $\mathrm{YBO}_{3}: \mathrm{Tb}^{3+}, \mathrm{Eu}^{3+}$ for white light emitting diodes. J. Mater. Chem. 2013, 1, 7202-7207. [CrossRef]

11. Lokeswara Reddy, G.V.; Rama Moorthy, L.; Chengaiah, T.; Bungala Chinna, J. Multi-color emission tunability and energy transfer studies of $\mathrm{YAl}_{3}\left(\mathrm{BO}_{3}\right)_{4}: \mathrm{Eu}^{3+} / \mathrm{Tb}^{3+}$ phosphors. Ceram. Int. 2014, 40, 3399-3410. [CrossRef]

12. Lokeswara Reddy, G.V.; Rama Moorthy, L.; Packiyaraj, P.; Jamalaiah, B.C. Optical characterization of $\mathrm{YAl}_{3}\left(\mathrm{BO}_{3}\right)_{4}: \mathrm{Dy}^{3+}-\mathrm{Tm}^{3+}$ phosphors under near UV excitation. Opt. Mater. 2013, 35, 2138-2145. [CrossRef]

13. Qi, Y.; Zhu, L.; Jiang, P.; Gao, W.; Cong, R.; Yang, T. Photoluminescence of complete solid solutions $\alpha-\mathrm{Y}_{1-x} \mathrm{Eu}_{x} \mathrm{~B}_{5} \mathrm{O}_{9}$ by sol-gel synthesis and thermal decomposition from $\mathrm{Y}_{1-x} \mathrm{Eu}_{x}\left[\mathrm{~B}_{6} \mathrm{O}_{9}(\mathrm{OH})_{3}\right]$. J. Solid State Chem. 2019, 277, 731-737. [CrossRef]

14. Zobetz, E. Geometrische Größen und einfache Modellrechnungen für $\mathrm{BO}_{4}$-Gruppen. Z. Kristallogr. 1990, 191, 45-57. [CrossRef]

15. Hawthorne, F.C.; Burns, P.C.; Grice, J.D. Boron: Mineralogy, Petrology, and Geochemistry. In Reviews in Mineralogy; Anovitz, L.M., Grew, E.S., Eds.; Mineralogical Society of America: Washington, DC, USA, 1996; Volume 33.

16. Brown, I.D.; Altermatt, D. Bond-Valence Parameters Obtained from a Systematic Analysis of the Inorganic Crystal Structure Database. Acta Crystallogr. 1985, 41, 244-247. [CrossRef]

17. Brese, N.E.; O'Keeffe, M. Bond-Valence Parameters for Solids. Acta Crystallogr. 1991, 47, 192-197. [CrossRef]

18. Hoppe, R.; Voigt, S.; Glaum, H.; Kissel, J.; Müller, H.P.; Bernet, K. A new route to charge distribution in ionic solids. J. Less-Common Met. 1989, 156, 105-122. [CrossRef]

19. Binnemanns, K. Interpretation of europium(III) spectra. Coordin. Chem. Rev. 2015, 295, 1-45. [CrossRef]

20. Dieke, G.H. Spectra and Energy Levels of Rare Earth Ions in Crystals; InterScience, Johan Wiley and Sons: New York, NY, USA, 1968.

21. Walker, D.; Carpenter, M.A.; Hitch, C.M. Some simplifications to multianvil devoces for high pressure experiments. Am. Mineral. 1990, 75, 1020-1028.

22. Walker, D. Lubrication, gasketing, and precision in multianvil exeriments. Am. Mineral. 1991, 76, 1092-1100.

23. Huppertz, H. Multianvil high-pressure/high-temperature synthesis in solid state chemistry. Z. Kristallogr. 2004, 219, 330-338. [CrossRef]

24. Sheldrick, G.M. SADABS, v2014/5; Bruker AXS Inc.: Madison, WI, USA, 2001.

25. Sheldrick, G.M. A short history of SHELX. Acta Crystallogr. 2008, 64, 112-122. [CrossRef] [PubMed]

26. Sheldrick, G.M. Crystal structure refinement with SHELX. Acta Crystallogr. 2015, 71, 3-8.

27. Farrugia, L.J. WinGX and ORTEP for Windows: An update. J. Appl. Crystallogr. 2012, 45, 849-854. [CrossRef]

(C) 2019 by the authors. Licensee MDPI, Basel, Switzerland. This article is an open access article distributed under the terms and conditions of the Creative Commons Attribution (CC BY) license (http://creativecommons.org/licenses/by/4.0/). 